\title{
Article
}

\section{A High-Throughput Screening System Based on Fluorescence-Activated Cell Sorting for the Directed Evolution of Chitinase A}

\author{
Gheorghita Menghiu ${ }^{1,2}(\mathbb{D})$, Vasile Ostafe ${ }^{2}(\mathbb{D})$, Radivoje Prodanović ${ }^{3}\left(\mathbb{D}\right.$, Rainer Fischer $^{1,4}$ and Raluca Ostafe $^{1,5, *}$ \\ 1 Institute for Biology VII, Molecular Biotechnology, RWTH Aachen University, Worringerweg 1, \\ 52074 Aachen, Germany; gheorghita.menghiu@e-uvt.ro (G.M.); fische70@purdue.edu (R.F.) \\ 2 Advanced Environmental Research Laboratories, Department of Biology-Chemistry, West University of \\ Timisoara, Oituz 4, 300086 Timisoara, Romania; vasile.ostafe@e-uvt.ro \\ 3 Faculty of Chemistry, University of Belgrade, Studentski trg 12-16, 11000 Belgrade, Serbia; \\ rprodano@chem.bg.ac.rs \\ 4 Departments of Biological Sciences and Chemistry, Purdue University, 207 S. Martin Jischke Dr., \\ West Lafayette, IN 47907, USA \\ 5 Purdue Institute of Inflammation, Immunology and Infectious Disease, Molecular Evolution, Protein \\ Engineering and Production, Purdue University, 207 S. Martin Jischke Dr., West Lafayette, IN 47907, USA \\ * Correspondence: rostafe@purdue.edu; Tel.: +1-317-765-496-4012
}

check for

updates

Citation: Menghiu, G.; Ostafe, V.; Prodanović, R.; Fischer, R.; Ostafe, R. A High-Throughput Screening System Based on

Fluorescence-Activated Cell Sorting for the Directed Evolution of Chitinase A. Int. J. Mol. Sci. 2021, 22, 3041. https://doi.org/10.3390/ ijms22063041

Academic Editor: Iolanda Francolini

Received: 3 February 2021

Accepted: 12 March 2021

Published: 16 March 2021

Publisher's Note: MDPI stays neutral with regard to jurisdictional claims in published maps and institutional affiliations.

Copyright: (C) 2021 by the authors Licensee MDPI, Basel, Switzerland. This article is an open access article distributed under the terms and conditions of the Creative Commons Attribution (CC BY) license (https:// creativecommons.org/licenses/by/ $4.0 /)$.

\begin{abstract}
Chitinases catalyze the degradation of chitin, a polymer of $N$-acetylglucosamine found in crustacean shells, insect cuticles, and fungal cell walls. There is great interest in the development of improved chitinases to address the environmental burden of chitin waste from the food processing industry as well as the potential medical, agricultural, and industrial uses of partially deacetylated chitin (chitosan) and its products (chito-oligosaccharides). The depolymerization of chitin can be achieved using chemical and physical treatments, but an enzymatic process would be more environmentally friendly and more sustainable. However, chitinases are slow-acting enzymes, limiting their biotechnological exploitation, although this can be overcome by molecular evolution approaches to enhance the features required for specific applications. The two main goals of this study were the development of a high-throughput screening system for chitinase activity (which could be extrapolated to other hydrolytic enzymes), and the deployment of this new method to select improved chitinase variants. We therefore cloned and expressed the Bacillus licheniformis DSM8785 chitinase A (chiA) gene in Escherichia coli BL21 (DE3) cells and generated a mutant library by error-prone PCR. We then developed a screening method based on fluorescence-activated cell sorting (FACS) using the model substrate 4-methylumbelliferyl $\beta-\mathrm{D}-N, N^{\prime}, N^{\prime \prime}$-triacetyl chitotrioside to identify improved enzymes. We prevented cross-talk between emulsion compartments caused by the hydrophobicity of 4-methylumbelliferone, the fluorescent product of the enzymatic reaction, by incorporating cyclodextrins into the aqueous phases. We also addressed the toxicity of long-term chi $\mathrm{A}$ expression in E. coli by limiting the reaction time. We identified 12 mutants containing 2-8 mutations per gene resulting in up to twofold higher activity than wild-type ChiA.
\end{abstract}

Keywords: FACS; protein engineering; error-prone PCR; mutants; bactericidal effect; improved enzymes; fluorescence assay

\section{Introduction}

Chitin is an insoluble, high-molecular-weight polymer comprising linear chains of $\beta(1,4)$-linked $N$-acetyl-D-glucosamine (Figure S1). It is the second most abundant biopolymer on the earth after cellulose, and is a major structural polysaccharide in insects, crustaceans, and fungi [1]. Massive quantities of chitin waste are generated by the processing of crabs, shrimps, and lobsters for food [2]. The natural degradation of chitin takes a long time because the polymer is insoluble and highly crystalline, and the accumulation of 
chitin waste is increasingly seen as an environmental burden, especially in countries with a prominent shellfish industry [3,4]. Efficient and environmentally friendly methods are required to convert chitin into valuable products such as chitosan oligomers, which are shorter-chain soluble products containing mixtures of $\beta$-(1,4)-linked D-glucosamine and $\mathrm{N}$-acetyl-D-glucosamine. They are known for their bioactive properties, including antimicrobial, immunomodulatory, and antioxidant activities that can be exploited in medicine, agriculture, food processing, water purification, and cosmetics [5-7]. The enzymatic production of chitosan oligomers from chitin is favored over physical and chemical treatments that involve harsh conditions. Enzymes that catalyze the hydrolysis of chitin are known as chitinases (EC 3.2.1.14), but the practical application of natural chitinases is limited by their low activity [8].

The disadvantages of wild-type chitinases can be overcome by combining heterologous expression with the redesign of chitinases using molecular evolution, which involves consecutive rounds of mutation and selection to isolate clones with improved properties. Directed evolution has been applied to a variety of enzymes with industrial applications, such as glucose oxidase [9,10], P450 monooxygenases [11], cellulases [12], peroxidases [13], cellobiose dehydrogenase [14], transaminases [15], esterases [16], lipases [17], proteases [18], and many more. However, there are only a few examples of the directed evolution of chitinases [19-21].

Several methods are readily available for the introduction of mutations at the gene level and have been used reliably for years [22]. Random mutagenesis by error-prone PCR is one such method that is widely used to generate enzyme libraries of up to $10^{8}-10^{12}$ variants $[23,24]$. However, complete screening of such complex libraries is not possible using any current method. The traditionally slow process of library screening has been accelerated in recent years by high-throughput screening using integrated robotic systems that transport assay microtiter plates (MTPs) from station to station for sample and reagent addition, mixing, incubation, and detection. This allows the sampling of $10^{4}-10^{6}$ variants in months [25-27]. But screening can be very expensive in terms of upfront investment in equipment as well as running costs associated with plastic consumables and the substrates needed for the reactions.

In the last decade, ultrahigh-throughput screening systems based on flow cytometry have been used for the screening of various enzymes [9,28-33]. Fluorescence-activated cell sorting (FACS) has gradually emerged as a tool for the screening of enzyme libraries due to its high sensitivity and ability to test up to $10^{7}$ enzyme variants per day [34], allowing the isolation of variants with improved activity, altered substrate specificity, or even novel functions [35]. Despite its great potential for enzyme evolution, FACS screening is still not widely used due to limited assay compatibility and the need to preserve the genotype-phenotype linkage during screening. Robotic or manual screening in MTPs is still the method of choice in most directed evolution laboratories due to the compatibility of the system with a variety of common assay formats such as luminescence, absorbance, fluorescence, and even mass spectrometry. Another advantage is that the link between the phenotype and mutant genotype is preserved by enclosing each reaction in a single well during the screening process.

In FACS-based screening, the detection assay is limited to fluorescence and the connection between genotype and phenotype is more difficult to maintain. One solution is to create artificial compartments around the cells that would keep the product of the enzymatic reaction (phenotype) connected to the cells expressing the mutant enzyme (genotype). One way to create such a barrier is the use of water-in-oil-in-water double emulsions. This in turn limits the pool of usable substrates because hydrophobic compounds diffuse out of the emulsion, and many fluorescent products are hydrophobic. The only commercially available substrate for chitinase is $\beta-N, N^{\prime}, N^{\prime \prime}$-triacetylchitotrioside (4MUTC), which forms a hydrophobic product, so we considered this as a model to overcome the diffusion of a hydrophobic product from the emulsion compartments and therefore increase the range of substrates that can be used with FACS-based screening for other enzyme classes. 
Here we describe the development of a FACS-based screening assay to identify improved variants of the chitinase ChiA from Bacillus licheniformis DSM8785. This enzyme was chosen as a starting point for our experiments because the sequence has been successfully expressed in Escherichia coli [4]. The chiA gene was cloned in the periplasmic expression vector $\mathrm{pET} 22 \mathrm{~b}(+)$ and expressed in E. coli BL21 (DE3) cells for molecular evolution by error-prone PCR, aiming to generate variants with greater activity. The periplasmic space was targeted because enzyme activity can be detected without cell lysis, depending on the substrate size. We optimized several parameters such as the chiA expression time and the duration of enzyme incubation with the fluorogenic substrate 4MUTC in the emulsion, and tried various additives in the emulsion system in order to keep the hydrophobic product from diffusing out of the droplet. The selected ChiA mutants were tested in MTP assays to compare their activities to the wild-type variant.

\section{Results and Discussion}

\subsection{Development of the FACS Assay}

Only three previous studies describe the directed evolution of chitinases, all of which involve low-throughput screening methods based on agar plate or MTP assays [19-21]. The natural substrate of ChiA is chitin or partially acetylated chitosan, because it has an absolute requirement for $\mathrm{N}$-acetyl-D-glucosamine and cleaves glycosidic bonds at random internal sites immediately downstream of an $\mathrm{N}$-acetyl-D-glucosamine unit [36]. Chitinase activity on chitin or chitosan is usually measured by detecting the reducing ends of polysaccharide fragments with 3,5-dinitrosalicylic acid (DNS) [37]. However, the DNS assay and other reducing-end detection methods are end-point reactions, so multiple aliquots from the reaction mix must be sampled at different time points. This method is therefore cumbersome and unsuitable for high-throughput screening. In addition, FACS requires the formation of a fluorescent product.

FACS-based screening methods using whole cells and double emulsions have been reported for multiple enzymes, but none of them have used hydrophobic products in the screening steps $[9,28-33]$. Hydrophobic products are challenging because they diffuse from the emulsion compartments, but 4MUTC is the only commercially available substrate for chitinase. The use of other substrates would require de novo organic synthesis, which is beyond the scope of our study. Furthermore, umbelliferyl substrates are commonly used for multiple enzymes (xylanase, glucose oxidase, glycosidase, cellulase, deacetylase, phosphatase, and others), providing additional justification for attempting to make FACSbased screening compatible with hydrophobic substrates [38-40]. We therefore selected the synthetic fluorogenic substrate 4MUTC for the detection of chitinase activity.

Esters of 4-methylumbelliferone (4MU) do not fluoresce unless cleaved to release the fluorophore. The assay for ChiA activity is therefore based on the hydrolysis of $4 \mathrm{MUTC}$ and the detection of the cleavage product $4 \mathrm{MU}$, which emits a signal at $460 \mathrm{~nm}$ when excited at $365 \mathrm{~nm}$ (Figure 1a). The assay was verified in MTP format, comparing E. coli cells expressing chiA to those transformed with the empty vector as negative controls (Figure $1 b$ ).

The assay was also tested in double emulsions, using samples comprising $100 \%$ positive or $100 \%$ negative cells as well as samples comprising different proportions of positive and negative cells, mimicking real libraries (Figure 1c). We found that the assay was sensitive to the proportion of positive cells in the mix because the positive droplet population (red) increased in line with the proportion of cells expressing chiA available in the mix, in agreement with earlier studies $[9,41]$. However, we observed a decline in the level of fluorescent product if the emulsions were incubated for longer time (Figure 1d), probably reflecting the hydrophobic nature of $4 \mathrm{MU}$, which can diffuse out of the internal water phase of the emulsion system through the oil phase and, potentially, into other droplets. 
(a)

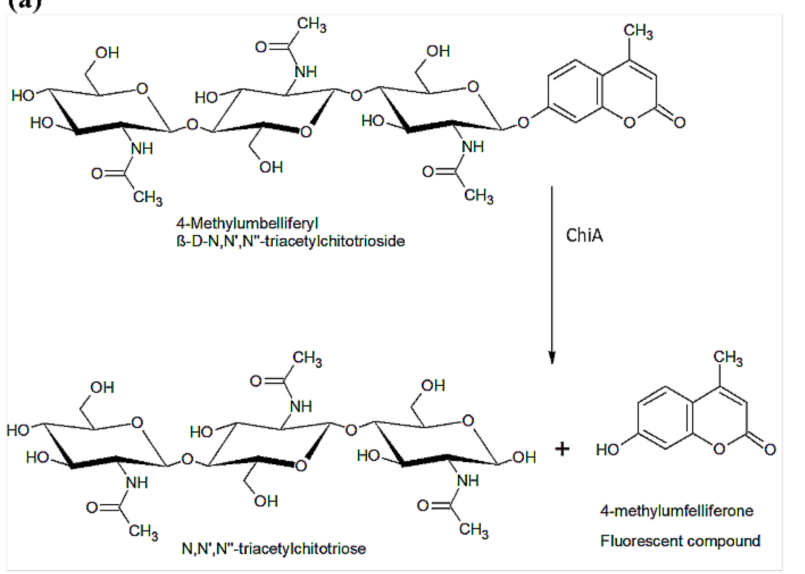

(c)
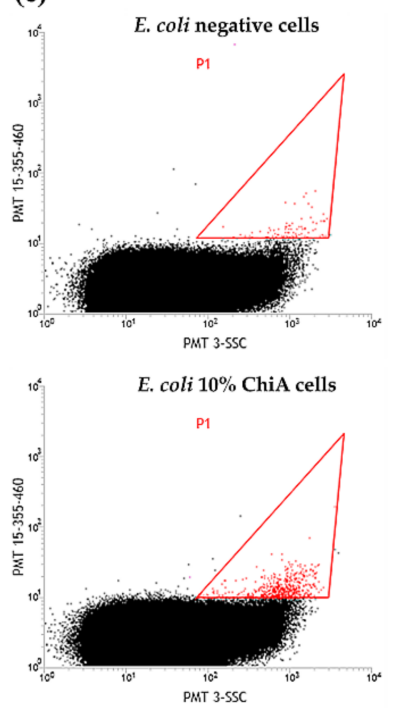
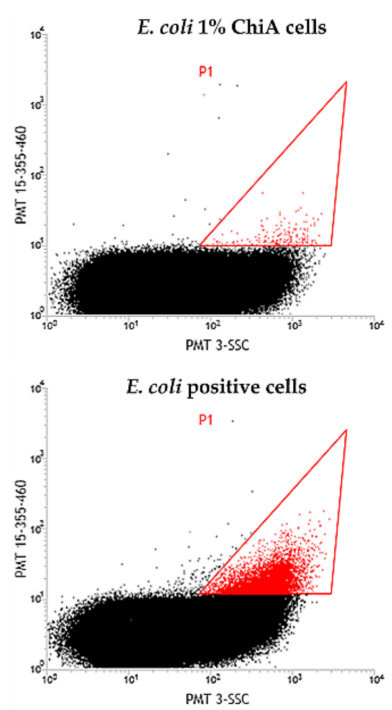

(b)

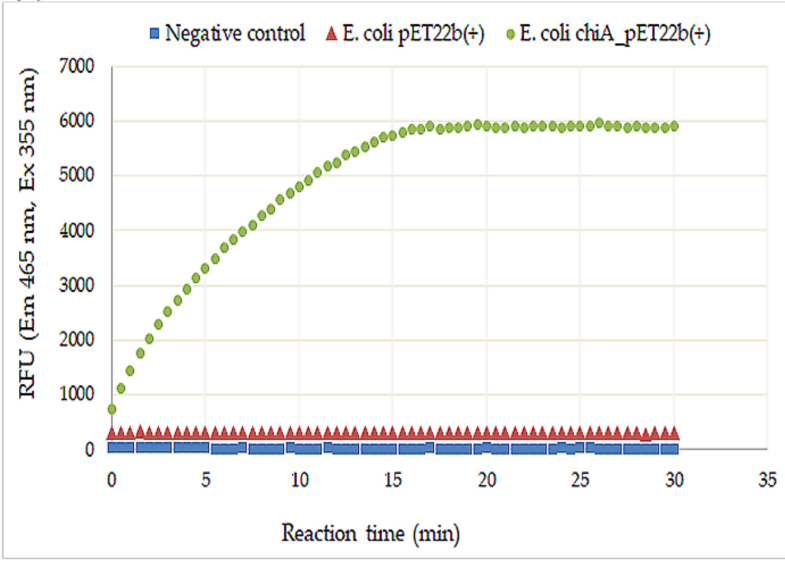

(d)
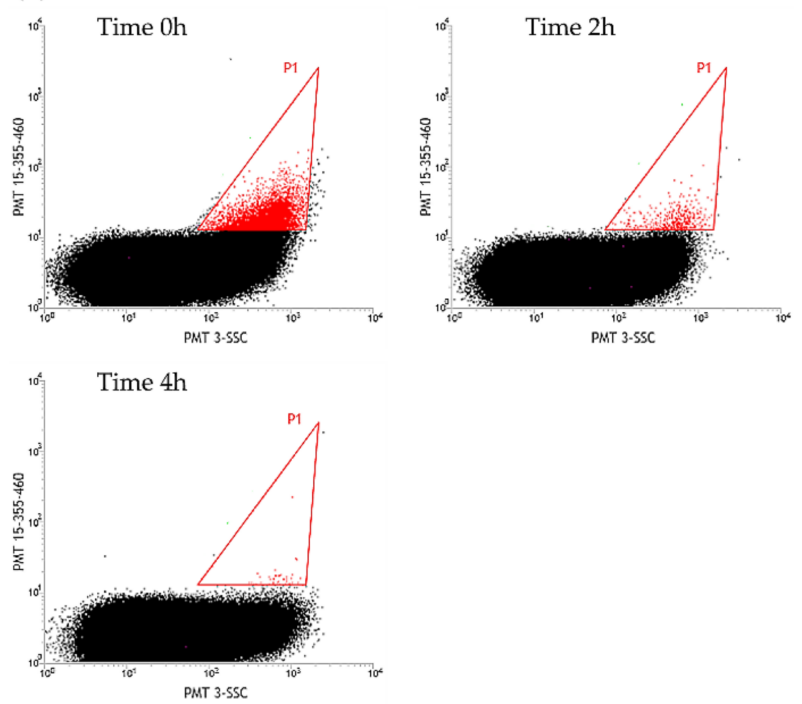

Figure 1. The synthetic fluorogenic substrate 4-methylumbelliferyl $\beta-D-N, N^{\prime}, N^{\prime \prime}$-triacetyl chitotrioside (4MUTC) was used for the detection of chitinase activity. (a) ChiA cleaves 4MUTC to generate the fluorescent product 4-methylumbelliferone (4MU) and $N, N^{\prime}, N^{\prime \prime}$-triacetylchitotriose. (b) MTP fluorescence assay using 4MUTC as the substrate for ChiA. (c) FACS response of E. coli cells containing ChiA in emulsions. Samples comprising $100 \%$ positive (E. coli chiA_pET22b+) or $100 \%$ negative cells (E. coli pET22b+) as well as samples comprising different proportions of positive and negative cells were tested. The positive droplet population is shown in red. (d) Decay of the FACS response of E. coli cells containing ChiA over time, in double emulsions.

If $4 \mathrm{MU}$ leaks from the emulsion droplet containing the positive cell in which it was created, this risks the generation of false-negative results. Furthermore, if the escaping $4 \mathrm{MU}$ enters droplets that lack chitinase activity, this risks the generation of false-positive results. The first issue can be addressed by inspecting the flow cytometry recordings over time but the second cannot, yet would nevertheless influence the sorting efficiency. To ensure that $4 \mathrm{MU}$ remains within the emulsions and does not travel across the hydrophobic layers, we added methyl- $\beta$-cyclodextrin (MCD) and 2-hydroxypropyl- $\beta$-cyclodextrin $(\mathrm{HCD})$ to the droplet phases to test their retention ability (the structures of MCD and HCD are presented in Figure S2).

Cyclodextrins (CDs) are cyclic oligosaccharides with a hydrophilic outer surface and a lipophilic central cavity, allowing them to act as molecular containers by entrapping guest particles or complex inclusions [42]. CDs have therefore been used to prevent crosstalk between emulsion droplets [43]. The partition of $4 \mathrm{MU}$ between the water and oil phases used for the preparation of double emulsions was determined by measuring 
the fluorescence in a simple biphasic mixture after incubation with 4MU for $1 \mathrm{~h}$. Different types and concentrations of CDs were added to the water phase to evaluate their ability to retain $4 \mathrm{MU}$, revealing that a 100 -fold molar excess of HCD over $4 \mathrm{MU}$ keeps more than $95 \%$ of $4 \mathrm{MU}$ in the water phase (Figure 2a).

(a)

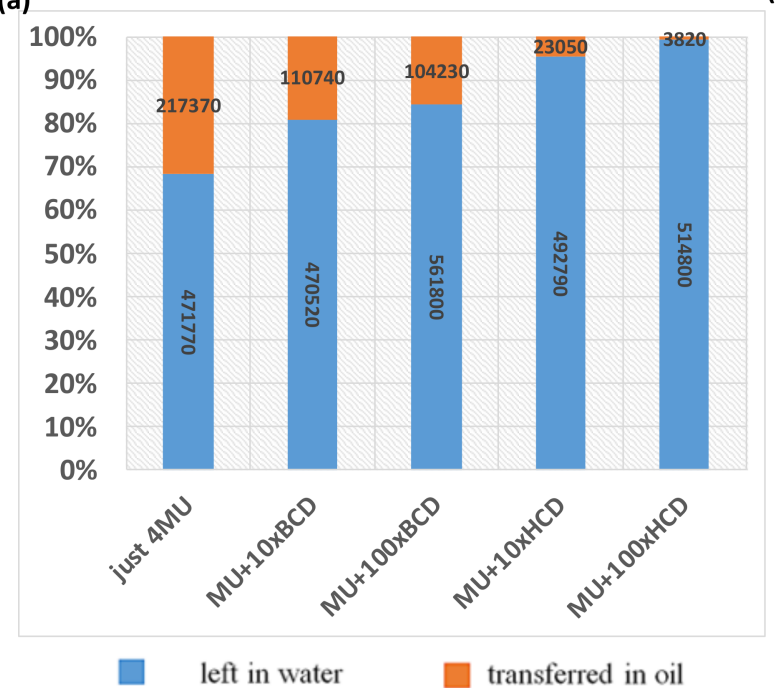

(b)

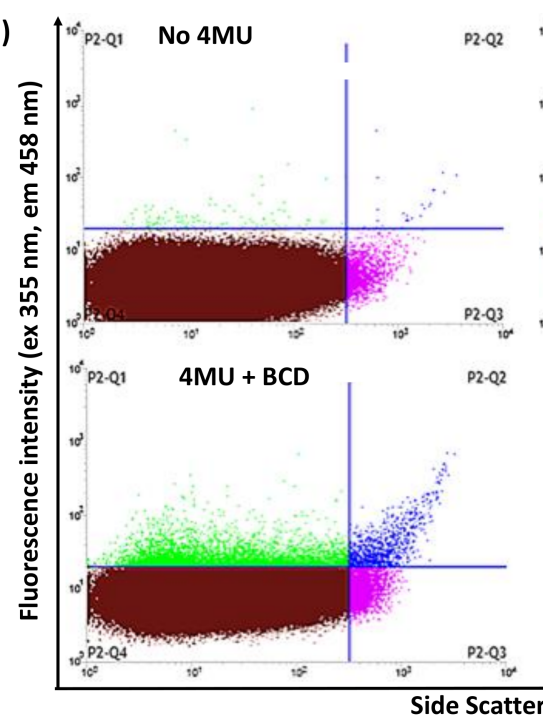

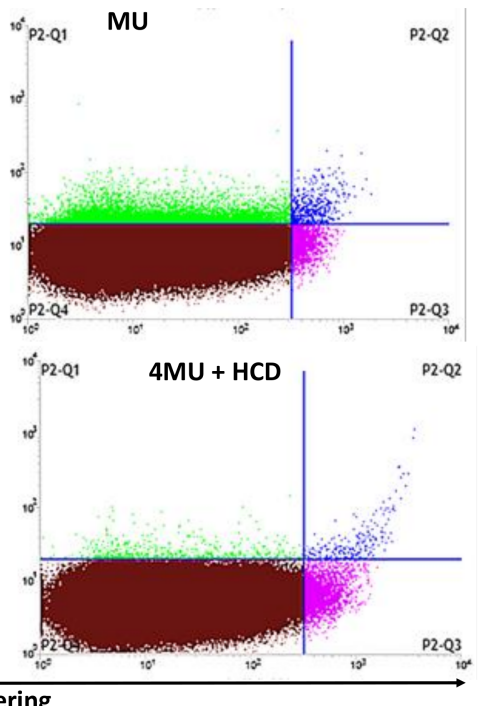
$\stackrel{\text { P. }^{2}}{\longrightarrow}$

Figure 2. Analysis of cyclodextrins for the retention of 4-methylumbelliferone (4MU) in a simple biphasic mixture and single emulsions. (a) Partition coefficient of $4 \mathrm{MU}$ between the oil and water phases of a simple mixture, showing the relative fluorescent units (RFUs) measured in each phase. (b) FACS analysis of 4MU, 4MU+MCD, and 4MU+HCD in the external phase of single oil-in-water emulsions (ABIL EM-CMC-Triton X-100).

To test the performance of HCD in a real emulsion system but with lower complexity than the double emulsions used for the encapsulation of cells, we created a single oil-inwater emulsion using the same oil/detergent combination. We then added $4 \mathrm{MU}$ to the external water phase before the emulsions were diluted. The samples were incubated at room temperature for $1 \mathrm{~h}$ and diluted 10-fold for FACS analysis. The presence of positive (green droplets) in the P2-Q1 quarter confirmed that 4MU entered the oil system in the absence of CDs but was retained more efficiently when HCD was present in the water phase (Figure $2 \mathrm{~b}$ ). We also tested a perfluorinated oil and detergent that should dissolve neither hydrophilic nor hydrophobic compounds [44], but 4MU was highly soluble in the oil and the addition of CDs did not prevent the uptake of 4MU by the oil phase (Figure S3).

The single-emulsion experiments confirmed that CDs are necessary to limit the escape of $4 \mathrm{MU}$ from the water phase containing positive cells expressing ChiA, and we assumed that the same was likely to be the case for double emulsions. To limit the likelihood of cross-talk between droplets even further, we also added HCD to the external water phase of the double emulsions to provide insurance in case the HCD in the internal aqueous compartment was insufficient to prevent the leakage of $4 \mathrm{MU}$ or in the event of disruption of the oil layer, which would make the inner and outer water phases contiguous and would dilute the HCD in the inner phase. Using these optimized conditions, we prepared double emulsions with $4 \mathrm{MU}$ in the inner water phase, with and without HCD also in the external water phase. As a third variant, we also added horseradish peroxidase (HRP) and $\mathrm{H}_{2} \mathrm{O}_{2}$ solely to the outer water phase, so that any $4 \mathrm{MU}$ reaching that compartment would be oxidized to a nonfluorescent product [45]. The emulsions containing HCD in the internal and external water phase and HRP in the external water phase showed the lowest cross-talk (Figure 3) and we therefore replicated these conditions for further experiments. 


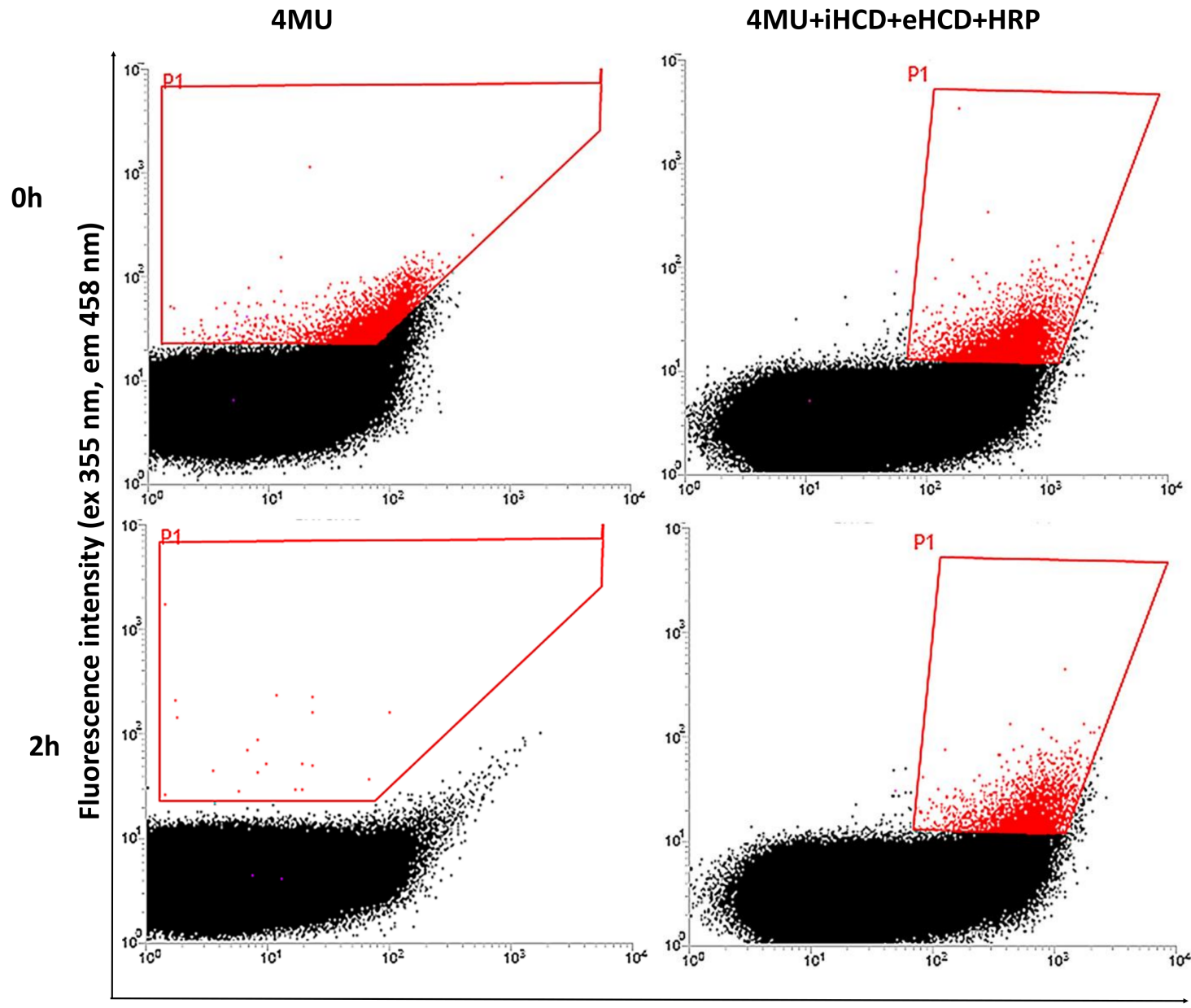

Side Scattering

Figure 3. FACS analysis of 4-methylumbelliferone (4MU), 4MU+HCD in the internal phase (iHCD) and external phase $(\mathrm{eHCD})+\mathrm{HRP}$, in double water-oil-water emulsions, after reaction for $2 \mathrm{~h}$.

\subsection{Sorting of Reference and Mutant ChiA Gene Libraries}

Using the optimized system containing HCD in the inner phase, and HCD, HRP, and $\mathrm{H}_{2} \mathrm{O}_{2}$ in the outer phase, we prepared reference libraries containing $5 \%$ ChiA-positive cells mixed with $95 \%$ nonexpressing cells and compartmentalized them in double emulsions. After a reaction time of $1 \mathrm{~h}$, we sorted 1000 positive events onto agar plates. However, we recovered fewer than 300 colonies from the plates and none of them were positive. Importantly, we also plated cells before sorting as a control, and despite the initial mix containing $5 \%$ positive cells, less than $1 \%$ of cells recovered from the presorting plate were positive. This suggested that the ChiA is toxic to the cells, which has previously been reported and attributed to the hydrolysis of host cell wall polysaccharides [46].

Viability tests revealed that the expression of ChiA was bactericidal to E. coli cells after $18 \mathrm{~h}$, resulting in the recovery of less than $0.6 \%$ of the colonies (Figure 4 ). The washing steps and the reaction with 4MUTC caused additional weak bactericidal effects. In contrast, empty vector control cells grew vigorously, as did cells expressing ChiA for 2-6 h, confirming that the main bactericidal factor was the long-term expression of ChiA. E. coli is already used for the production of recombinant chitinase and the product accumulates in the cytoplasm, but even in these cases some chitinase was detected in the extracellular environment, suggesting a certain degree of cell lysis [47-49]. These publications focused on overall expression levels or screening in agar plate or MTP assays, where a population of $>10^{8}$ identical clones was assayed per well or spot, therefore cell lysis was not a concern. In contrast, we are testing individual cells and the maintenance of cell viability is therefore 
much more important. In our system, the chiA gene is cloned in frame with the pelB sequence such that ChiA accumulates in the periplasm, bringing it into direct contact with the cell wall and thus triggering cell lysis. This issue is probably compounded by encapsulating the cells in picoliter compartments, which results in a much higher effective chitinase concentration around the cell. We therefore reduced the chiA expression time to $4 \mathrm{~h}$, which does not affect cell viability but still allows the detection of ChiA activity. Using these optimizations, we recreated the emulsion using the mutant library. After sorting the positive events, we achieved a 17 -fold enrichment of the positive cell population.

(a)

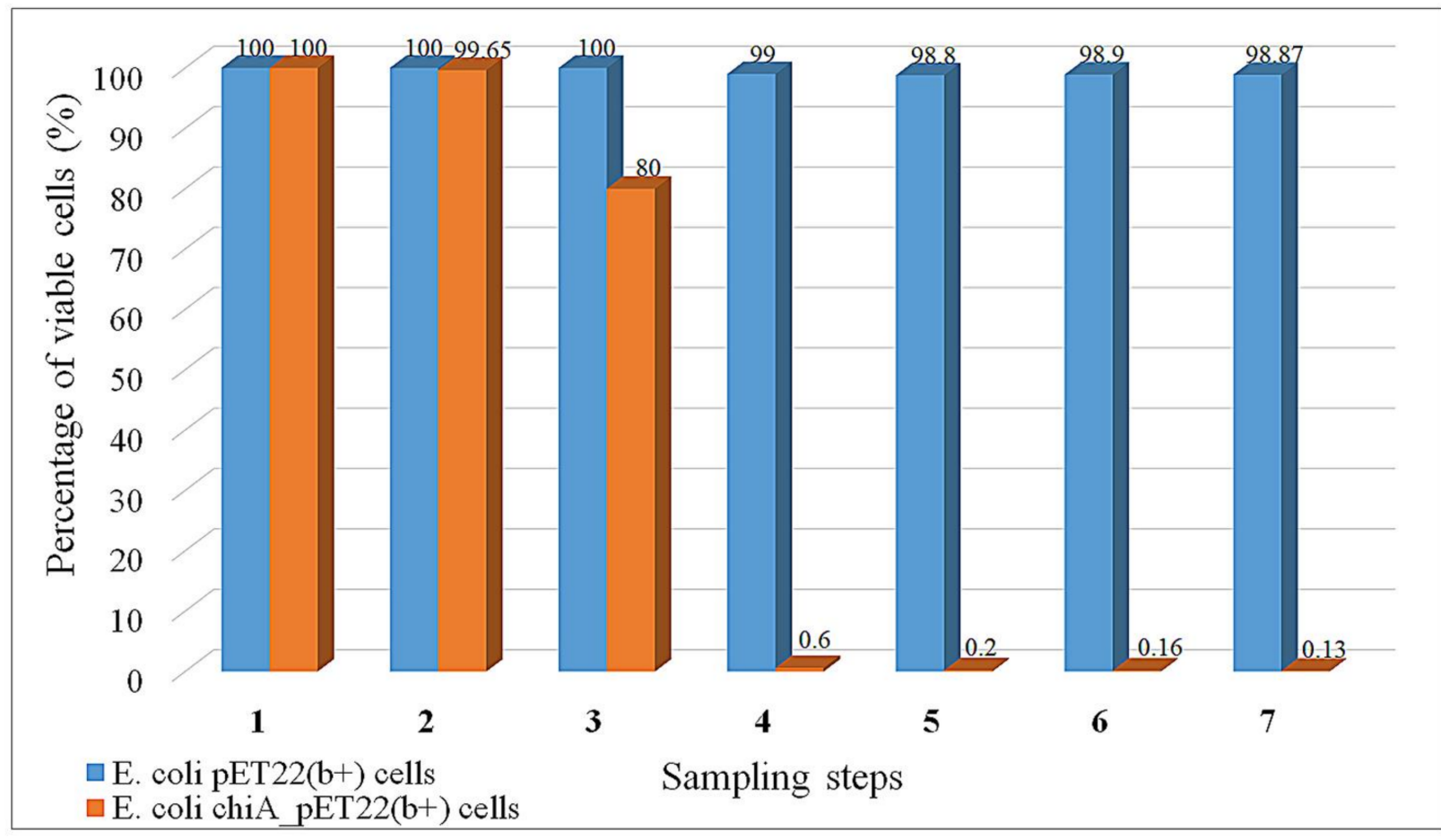

(b)

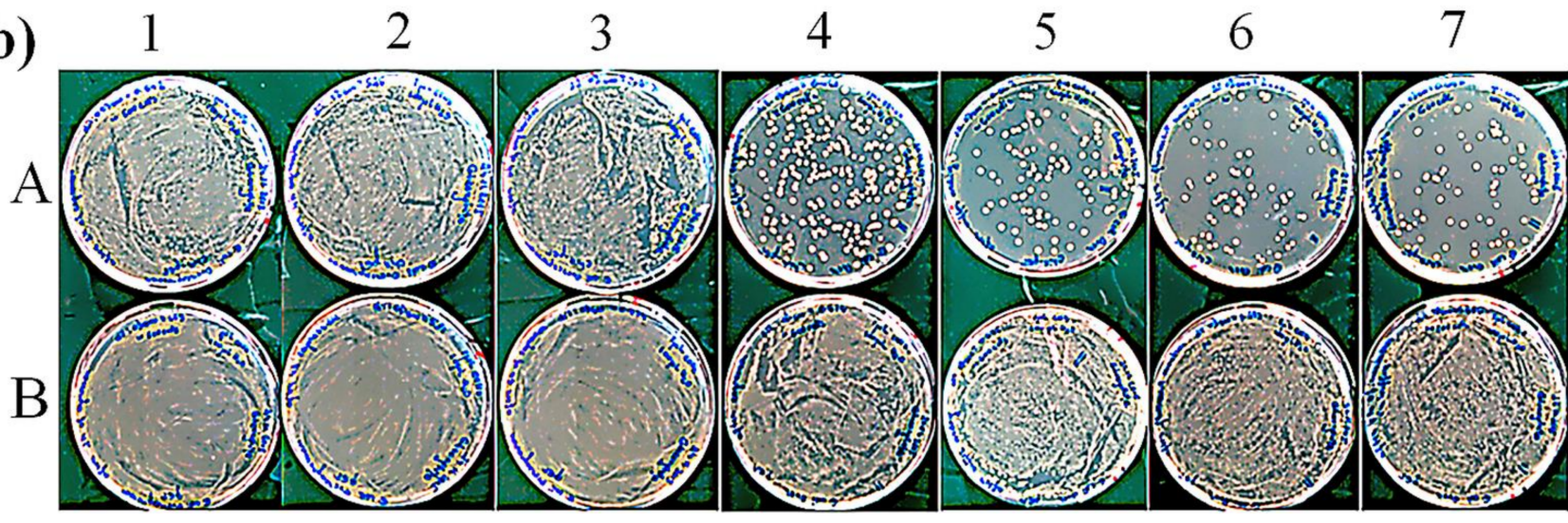

Figure 4. Cell viability assay at different phases of expression, cell washing, and enzymatic reaction. (a) Percentage of cell viability. (b) Plate assay, corresponding to the quantitative data shown in (a), comparing E. coli BL21 (DE3) cells transformed with chiA_pET22b or the empty pET22b(+) vector. Sampling steps on $x$-axis: $1=2 \mathrm{~h}$ expression, $2=4 \mathrm{~h}$ expression, $3=6 \mathrm{~h}$ expression, $4=18 \mathrm{~h}$ expression, $5=18 \mathrm{~h}$ expression and washing, $6=18 \mathrm{~h}$ expression, washing, and enzymatic reaction (30 $\mathrm{min}), 7=18 \mathrm{~h}$ expression, washing, and enzymatic reaction $(4 \mathrm{~h})$. Data are means \pm standard errors representing $\mathrm{n}=3$ experiments. 


\subsection{Screening of Mutants Using the MTP-Based Fluorescence Assay}

The mutants were initially tested using an agar plate assay. Clones showing promising activity were collected and reanalyzed using the MTP format for precise quantitation (Figure 2.4). We identified 12 mutants with higher activity than wild-type ChiA, one of which (DH08) was 100\% more active. The positions of the mutations in all 12 clones were identified by DNA sequencing (Table 1).

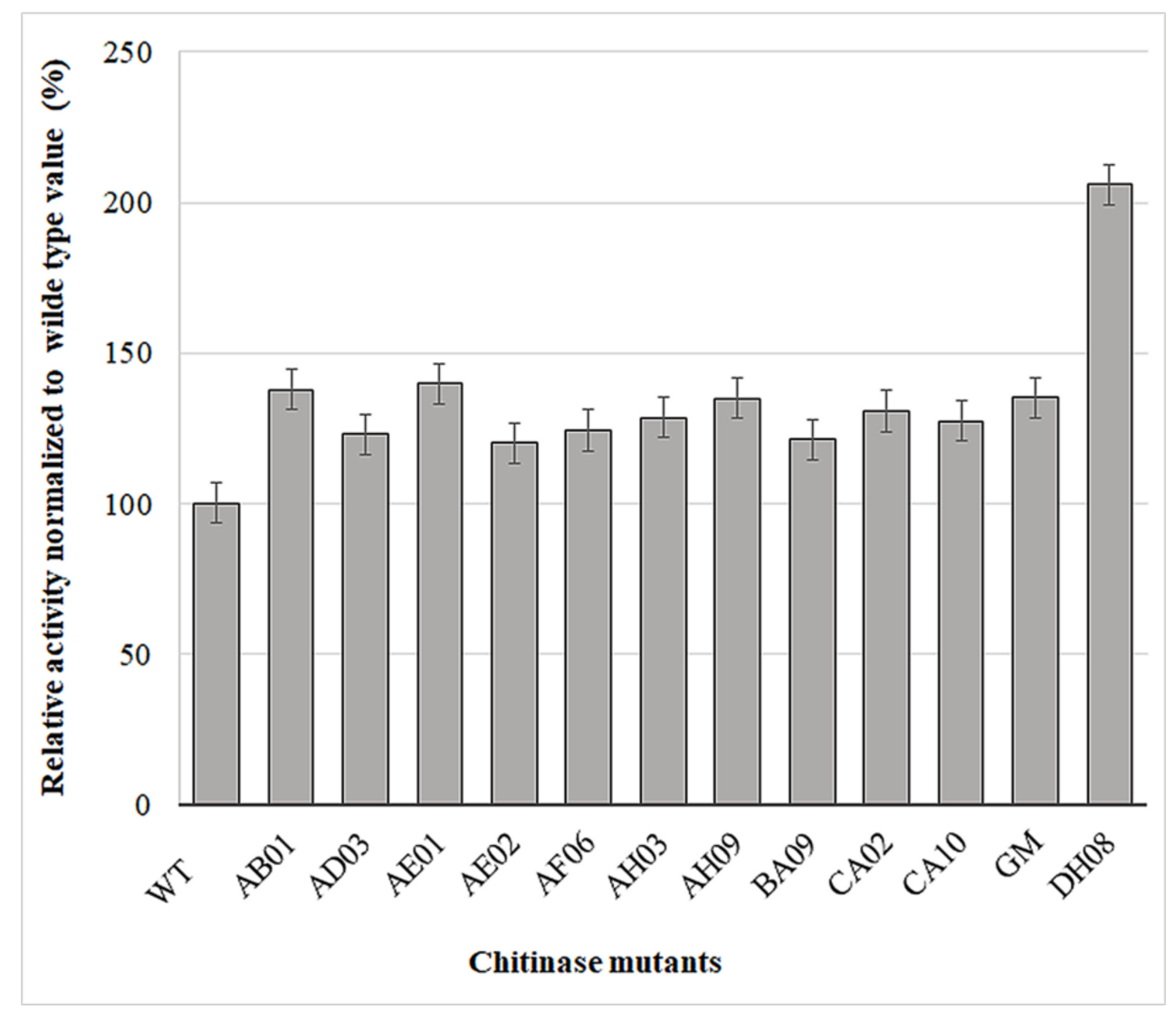

Figure 5. Relative activity of 12 ChiA mutants identified by FACS-based screening, normalized to wild-type ChiA. Data are means \pm standard errors representing $n=3$ experiments.

\subsection{Homology Modeling of ChiA}

A crystal structure for ChiA is not yet available. We therefore constructed a homology model for the enzyme based on the 1edq sequence, which has 30\% similarity to ChiA. Part of the $\mathrm{N}$-terminal and C-terminal regions could not be modeled due to their low homology to any existing structures. Therefore, the mutations in those regions are not represented. As shown in Figure 6, the mutations obtained in this study are positioned at a distance of more than $5 \AA$ from the active site, as evaluated using Chimera software [50], therefore we assume they do not have a direct impact on substrate binding or catalytic activity. The 12 variants we identified feature a total of 49 mutations. Only one mutation (E389D) was found in two different mutants (AB01 and GM). The rest of the mutations were unique and distributed over the entire sequence of the protein. We did not observe any clustering or any regions with a higher mutational load. Interestingly, all the mutations we recovered from a screen of $10^{6}$ random variants were located in loop regions or at the edges of $\alpha$-helices or $\beta$-sheets, suggesting that secondary structures are highly conserved and do not tolerate substitutions. 
Table 1. Positions of mutations in the 12 ChiA mutants identified by FACS-based screening. The sequences were analyzed using Vector NTI software. The color codes correspond to those in Figure 6.

\begin{tabular}{|c|c|c|c|}
\hline No & Mutants & $\begin{array}{l}\text { Mutation Points } \\
\text { Number }\end{array}$ & $\begin{array}{l}\text { Amino Acids } \\
\text { Replaced } \\
\text { (Mutations) }\end{array}$ \\
\hline 1 & ChiA (wild-type) & - & - \\
\hline 2 & AB01 & 5 & $\begin{array}{c}\text { D154E, F315L, } \\
\text { E389D, S530P, G568S }\end{array}$ \\
\hline 3 & AE01 & 8 & $\begin{array}{l}\text { V46I, P190A, N192K, } \\
\text { T295S, N446I, G516R, } \\
\text { T537M, R574Q }\end{array}$ \\
\hline 4 & AE02 & 6 & $\begin{array}{l}\text { K16I, A17V, W42R, } \\
\text { I87N, I252V, V474L }\end{array}$ \\
\hline 5 & AD03 & 2 & R448C, A471E \\
\hline 6 & AH03 & 2 & V484I, A506V \\
\hline 8 & AH09 & 7 & $\begin{array}{c}\text { K24N, S79L, R147L, } \\
\text { A218V, S230C, I292F, } \\
\text { S441P }\end{array}$ \\
\hline 7 & AF06 & 1 & Y362S \\
\hline 9 & BA09 & 4 & $\begin{array}{c}\text { L7S, N53S, V296L, } \\
\text { V304D }\end{array}$ \\
\hline 10 & CA02 & 4 & $\begin{array}{l}\text { D110N, P436T, } \\
\text { A443V, N469D }\end{array}$ \\
\hline 11 & CA10 & 2 & $\mathrm{~A} 165 \mathrm{~T}, \mathrm{D} 427 \mathrm{~N}$ \\
\hline 12 & GM & 5 & $\begin{array}{c}\text { M3R, G303D, Q369L, } \\
\text { E389D, T419M }\end{array}$ \\
\hline 13 & DH08 & 3 & $\begin{array}{l}\text { K128E, H130N, } \\
\text { D220Y }\end{array}$ \\
\hline
\end{tabular}

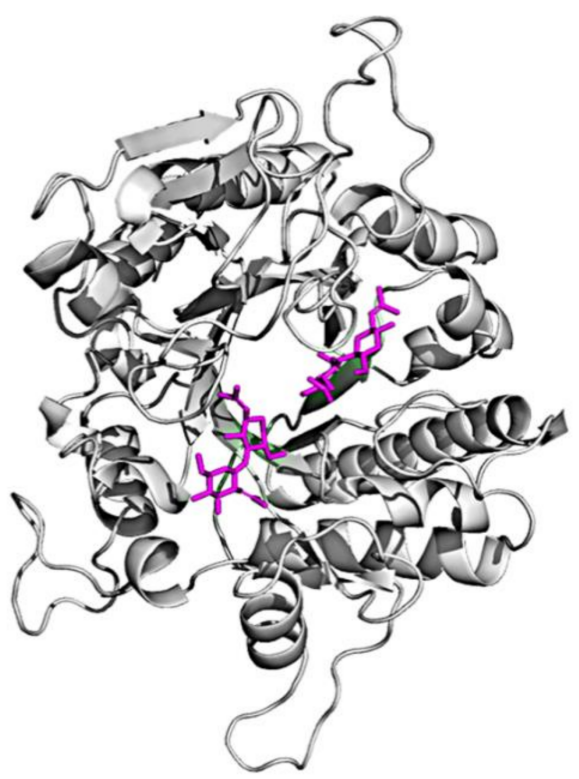

(a)

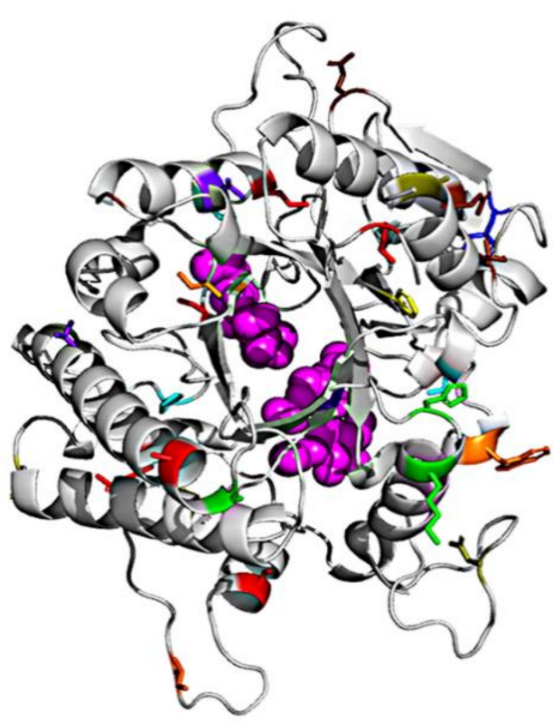

(b)

Figure 6. Backbone diagrams of chitinase. (a) Chitin substrate highlighted in the active site. (b) Mutations are represented by different colors corresponding to those in Table 1. 
Fourteen of the mutations we recovered (V46I, N53S, D110N, K128E, H130N, D153E, I252V, T295S, V296L, E389D, D427N, N468D, V484I, and R574Q) could be defined as conservative [51]. However, such mutations can still help to improve protein activity in the same manner as natural mutations that confer incremental increases in fitness and contribute specifically to stability [52]. The rest of the mutations were not conserved. An earlier study involving the directed evolution of chitinases, starting from the same B. licheniformis ChiA sequence used in our study [20], generated a variant containing five mutations, two of which were also recovered in our screen (Q369 and N468). This is interesting because the mutants in both cases were selected from a completely random library, suggesting these positions may be important for ChiA activity. Three of our mutants (P190, P436T, and S441P) involved exchanges that either removed or introduced proline residues, thus conferring the potential to change the flexibility of the polypeptide backbone. Mutations that replace charged with uncharged residues or vice versa may have a subtle effect on protein structure due to long-range electrostatic interactions [53]. We identified 16 such substitutions: K16I, K24N, W42R, D110N, K128E, H130N, D220Y, R147L, N192K, G303D, V304D, D427N, R448C, N469D, G516R, and R574Q.

All our variants contained multiple mutations, making it difficult to speculate on the importance of individual residues because there are no obvious explanations for the observed effects, as is often the case for mutants generated by directed evolution [54,55]. In order to better understand the structure-activity relationship, further investigations are required involving direct empirical testing and computational analysis. The evaluation of single mutants is currently underway, combined with molecular dynamics simulations.

\section{Materials and Methods}

\subsection{Chemicals and Enzymes}

Chemicals were purchased from Carl Roth (Karlsruhe, Germany) or Sigma-Aldrich (Taufkirchen, Germany) if not otherwise stated. NucleoSpin DNA purification kits were supplied by Macherey-Nagel (Düren, Germany). Pfu HF DNA polymerase, Taq DNA polymerase, and the GeneMorph II Random Mutagenesis kit were obtained from Agilent Technologies (Santa Clara, CA, USA). Phusion High-Fidelity DNA Polymerase and Dpn I were obtained from New England Biolabs (Ipswich, MA, USA).

\subsection{Directed Evolution of ChiA and Library Preparation}

The synthetic B. licheniformis DSM8785 chiA gene (GenBank accession number FJ465148) [4] was synthesized by GenScript Biotech (Piscataway, NJ, USA) and inserted into vector $\mathrm{pET} 22 \mathrm{~b}(+)$ for error-prone PCR as previously described [24].

\subsection{MTP Assay for ChiA Activity}

E. coli BL21 (DE3) OverExpress precultures carrying pET22b(+) or chiA_pET22b(+) were inoculated into lysogeny broth (LB) medium containing $0.1 \mathrm{mg} / \mathrm{mL}$ ampicillin at $\mathrm{OD}_{600}=0.1$ and incubated for $2 \mathrm{~h}$ at $37{ }^{\circ} \mathrm{C}$, shaking at $160 \mathrm{rpm}$, until the $\mathrm{OD}_{600}$ reached 0.8-1.0. Enzyme expression was initiated by adding $1 \mathrm{mM}$ isopropyl $\beta-\mathrm{D}-1-$ thiogalactopyranoside (IPTG) and incubating for $18 \mathrm{~h}$ as above. Cells were collected by centrifugation at $3000 \times g$ for $20 \mathrm{~min}$, then washed four times in $0.1 \mathrm{M}$ sodium acetate buffer ( $\mathrm{pH}$ 6.0) with intervening centrifugation steps at $11,000 \times g$ for $1 \mathrm{~min}$. Finally, the cells were resuspended in $100 \mu \mathrm{L} 0.1 \mathrm{M}$ sodium acetate buffer $(\mathrm{pH}$ 6.0) and $25 \mu \mathrm{L}$ of the suspension was transferred to the MTP and mixed with $25 \mu \mathrm{L} 0.5 \mathrm{mg} / \mathrm{mL} 4 \mathrm{MUTC}$. The reactions were monitored on a plate reader (excitation $355 \mathrm{~nm}$, emission $465 \mathrm{~nm}$ ) with shaking at every $30 \mathrm{~s}$.

\subsection{Cell Viability Assay}

Aliquots of cells $(1 \mu \mathrm{L})$ were removed $2,4,6$, and $18 \mathrm{~h}$ after the addition of IPTG and diluted with water to an $\mathrm{OD}_{600}$ of $0.6-0.8$. Then, $1 \mu \mathrm{L}$ aliquots from the diluted suspension were plated onto LB agar plates supplemented with $0.1 \mathrm{mg} / \mathrm{mL}$ ampicillin and incubated for $24 \mathrm{~h}$ at $37^{\circ} \mathrm{C}$ before counting the colonies. The remaining culture after $18 \mathrm{~h}$ was washed 
by four rounds of centrifugation and resuspension in $0.1 \mathrm{M}$ sodium acetate $(\mathrm{pH} 6.0)$ as above before resuspending in $100 \mu \mathrm{L}$ of the same buffer to provide a nonexposed stock suspension. Next, $1 \mu \mathrm{L}$ of the nonexposed stock was diluted to $\mathrm{OD}_{600}=0.6-0.8$, and $25 \mu \mathrm{L}$ of this diluted suspension was mixed with $25 \mu \mathrm{L} 0.5 \mathrm{mg} / \mathrm{mL}$ 4MUTC. After $30 \mathrm{~min}$ or $4 \mathrm{~h}$, the postexposure suspension was spread on LB agar plates supplemented with ampicillin as above, to test cell viability in the presence of 4MUTC. Another $1 \mu \mathrm{L}$ aliquot of the nonexposed stock was diluted to $\mathrm{OD}_{600}=0.6-0.8$ and spread on the LB agar plus ampicillin plates as a nonexposed control.

\subsection{FACS Assay}

The in vitro compartmentalization of bacteria was carried out as previously described [56] with the following modifications. The washed cells together with the reaction components from the MTP assay described above $(25 \mu \mathrm{L})$ were added to $250 \mu \mathrm{L}$ of the icecold oil phase comprising 1.5\% ( $v / v$ ) ABIL EM 90 (Evonik, Essen, Germany) in light mineral oil. The two phases were homogenized on ice in a $2 \mathrm{~mL}$ round-bottom cryotube for $3 \mathrm{~min}$ at $7000 \mathrm{rpm}$ using a MICCRA D1 homogenizer (ART Prozess \& Labortechnik, Müllheim, Germany). The second water phase $(500 \mu \mathrm{L})$ containing $1.5 \%(w / v)$ carboxymethylcellulose $(\mathrm{CMC})$ and $1 \%(v / v)$ Triton X-100 in PBS was added to the primary emulsion and homogenized on ice for $3 \mathrm{~min}$ at 10,000 rpm. We then diluted $10 \mu \mathrm{L}$ of each emulsion in $2 \mathrm{~mL}$ PBS for analysis on a BD FACS DiVa flow cytometer (BD, Franklin Lakes, NJ, USA) with the following parameters: one drop enrich sorting mode, $\mathrm{P} 2$ gate, photomultiplier tube (PMT) 15, 355-460 nm, PMT 3-SSC (side scatter). Events sorted at a throughput of 1000 were collected on LB agar plates supplemented with $0.1 \mathrm{mg} / \mathrm{mL}$ ampicillin and incubated overnight at $37^{\circ} \mathrm{C}$.

\subsection{Testing of Cyclodextrins and Different Oils}

For initial evaluation, single emulsions were prepared from (a) $2.9 \%(v / v)$ ABIL EM 90 and $1 \%(v / v)$ Triton X-100 in PBS; (b) 2.9\% $(v / v)$ ABIL EM 90, 1\% $(v / v)$ Triton X-100, and $1.5 \%(w / v)$ CMC in PBS, or (c) 2.9\% (v/v) ABIL EM 90, 1\% (v/v) Triton X-100, 1\% $(v / v)$ commercial Picosurf in HEFE 7300, and 1\% $(w / v)$ SDS. In each case, the emulsion was divided into three proportions, one of which was mixed with $1 \mathrm{mM} 4 \mathrm{MU}$, another with $1 \mathrm{mM} 4 \mathrm{MU}+100 \mathrm{mM} \mathrm{MCD}$, and the third with $1 \mathrm{mM} 4 \mathrm{MU}+100 \mathrm{mM}$ HCD.

For library screening, the initial emulsion obtained by mixing $500 \mu \mathrm{L} 2.9 \%(v / v)$ ABIL EM in mineral oil with $20 \mu \mathrm{L}$ cells and $10 \mu \mathrm{L} 1.32 \mathrm{mM}$ 4MUTC was divided in two portions of $250 \mu \mathrm{L}$, one of which was mixed with $10 \mu \mathrm{L} 100 \mathrm{mM} \mathrm{MCD}$ and the other with $10 \mu \mathrm{L}$ $100 \mathrm{mM}$ HCD. Both mixtures were homogenized for $3 \mathrm{~min}$ at 10,800 rpm before mixing with $500 \mu \mathrm{L} 1 \%(v / v)$ Triton X-100 in PBS and homogenizing again as above. The resulting emulsions were each divided into three portions of $250 \mu \mathrm{L}$. The first portion was used without further modification (MCD or HCD in the inner water phase only). The second portion was supplemented with $10 \mu \mathrm{L} 100 \mathrm{mM}$ MCD or HCD in the external water phase. The third portion was supplemented with $10 \mu \mathrm{L} 100 \mathrm{mM}$ MCD or HCD in the external water phase as well as $50 \mu \mathrm{L} 50 \mathrm{U} / \mathrm{mL} \mathrm{HRP}$ and $25 \mu \mathrm{L} 10 \mathrm{mM} \mathrm{H}_{2} \mathrm{O}_{2}$. All emulsions were diluted in PBS and analyzed by FACS, as described above.

\subsection{Sorting and Selection of ChiA Mutants}

The library emulsions were sorted after incubating them with the substrate for $1 \mathrm{~h}$ at room temperature. One thousand positive events were sorted and transferred to agar plates to evaluate the number of droplets containing viable cells. After $24 \mathrm{~h}, 50-100$ viable colonies were transferred to fresh agar plates containing $0.5 \%(w / v)$ colloidal chitin [37] and $1 \mathrm{mM} \mathrm{IPTG}$ at $37^{\circ} \mathrm{C}$. After chiA expression for $48 \mathrm{~h}$, the proportion of cells producing ChiA was evaluated by observing halo formation around the colonies, allowing us to calculate the overall percentage viability and chitinase expression. 


\subsection{MTP Fluorescence Assay}

Three hundred colonies representing positive mutants, 20 wild-type positive controls, and 20 vector-only negative controls were transferred to 96-well MTPs containing $200 \mu \mathrm{L}$ LB medium supplemented with $0.1 \mathrm{mg} / \mathrm{mL}$ ampicillin. The plates were incubated overnight at $37^{\circ} \mathrm{C}$, shaking at $900 \mathrm{rpm}$. Precultures $(5 \mu \mathrm{L})$ were transferred to $200 \mu \mathrm{L} \mathrm{LB}$ medium containing antibiotics and incubated overnight as above. From these precultures, $20 \mu \mathrm{L}$ of the suspension was transferred to fresh MTPs containing $200 \mu \mathrm{L}$ LB medium supplemented with $0.1 \mathrm{mg} / \mathrm{mL}$ ampicillin. After $3 \mathrm{~h}, 200 \mu \mathrm{L}$ of LB medium containing $0.1 \mathrm{mg} / \mathrm{mL}$ ampicillin and $2 \mathrm{mM}$ IPTG were added to induce chiA expression. After $18 \mathrm{~h}$, preliminary analysis of the mutant enzyme activity based on fluorescence allowed us to calculate the relative activity of the improved mutants compared to wild-type ChiA. The positions of the mutations were confirmed by DNA sequencing [57].

\subsection{Homology Modeling}

ChiA was modeled using SWISS-MODEL Workspace [58] and structure 1edq.1 as the template. This is a ChiA protein from Serratia marcescens with $31.57 \%$ sequences similarity to $B$. licheniformis DSM8785 ChiA.

\section{Conclusions}

A series of ChiA mutants with improved activity were generated using a combination of error-prone PCR for molecular evolution and flow cytometry for high-throughput screening of the resulting library. 4MUTC was selected as the fluorescent substrate for screening. The fluorescent product is hydrophobic, so we looked at multiple ways to prevent the leakage of the product from the emulsions. The best results with the lowest crosstalk were achieved using HDC, which was found to retain 4MU most efficiently. This approach was preferable to the use of a fluorogenic substrate that generates a hydrophilic fluorescent product because the latter would require a much more complex process of chemical synthesis. Our strategy will be useful for other screening applications using emulsions. It also extends the range of substrates that are compatible with high-throughput screening based on FACS.

An additional issue we encountered was the toxicity of ChiA activity in the E. coli host cells, which made it difficult to recover viable cells after sorting. We addressed this challenge by fine tuning the expression levels of the chiA gene. This approach worked well for the wild-type ChiA, but the mutants recovered from the library never exceeded the wild-type activity by more than twofold, suggesting that toxicity remains an issue for enzymes with much higher levels of activity in this assay. We are considering several strategies to overcome this drawback, including the testing of even shorter induction periods and the use of cell-free in vitro coupled transcription-translation systems which would not be dependent on cell survival. Despite these limitations, the current version of the assay enabled the recovery of 12 improved ChiA variants, in most cases featuring mutations in surface loops far from the active site. These data suggest that the activity of ChiA can be increased by introducing structural changes that have a broader effect, such as improving protein folding and flexibility (which facilitates the hydrolysis of insoluble and crystalline substrates) as well as overall stability. This is the first report describing an ultrahigh-throughput screening system for improving chitinase activity, and provides a new strategy that can lead us a step closer to finding chitinase variants suitable for the environmentally friendly degradation of chitinaceous waste in a sustainable way.

Supplementary Materials: The following are available online at https: / /www.mdpi.com/1422-0 067/22/6/3041/s1, Figure S1: Chemical structures of chitin and chitosan, Figure S2. Chemical structures of the cyclodextrins used to prevent leakage of the fluorescent product 4MU, Figure S3. FACS response of $4 \mathrm{MU}$, in the presence and absence of MCD/HCD, using a perfluorinated oil (PicoSurf) and SDS detergent, in double water-oil-water emulsions. 
Author Contributions: Conceptualization, R.O. and G.M.; methodology, G.M.; software, R.O.; validation, G.M., R.O., V.O., and R.P.; formal analysis, G.M.; investigation, G.M. and R.O.; writingoriginal draft preparation, G.M.; writing-review and editing, R.O., V.O., R.P., and R.F.; visualization, G.M.; supervision, R.O. and V.O.; project administration, R.O.; funding acquisition, R.F. and V.O. All authors have read and agreed to the published version of the manuscript.

Funding: G. Menghiu acknowledges support from the strategic grant POSDRU/159/1.5/S/137750: Project "Doctoral and postdoctoral programs support for increased competitiveness in exact sciences research" co-financed by the European Social Fund within the Sectorial Operational Program Human Resources Development 2007-2013. This research was funded by the GRANT PNIII-P3284, ChitoWound-Biotechnological tools implementation for new wound healing applications of byproducts from the crustacean seafood processing industry.

Institutional Review Board Statement: Not applicable.

Informed Consent Statement: Not applicable.

Data Availability Statement: Not applicable.

Conflicts of Interest: The authors declare no conflict of interest. The funders had no role in the design of the study; in the collection, analyses, or interpretation of data; in the writing of the manuscript, or in the decision to publish the results.

\section{References}

1. Lenardon, M.D.; Munro, C.A.; Gow, N.A. Chitin synthesis and fungal pathogenesis. Curr. Opin. Microbiol. $2010,13,416-423$. [CrossRef]

2. Yadav, M.; Goswami, P.; Paritosh, K.; Kumar, M.; Pareek, N.; Vivekanand, V. Seafood waste: A source for preparation of commercially employable chitin/chitosan materials. Bioresour. Bioprocess. 2019, 6, 1-20. [CrossRef]

3. Santos, V.P.; Marques, N.S.S.; Maia, P.C.S.V.; De Lima, M.A.B.; Franco, L.D.O.; De Campos-Takaki, G.M. Seafood waste as attractive source of chitin and chitosan production and their applications. Int. J. Mol. Sci. 2020, 21, 4290. [CrossRef]

4. Songsiriritthigul, C.; Lapboonrueng, S.; Pechsrichuang, P.; Pesatcha, P.; Yamabhai, M. Expression and characterization of Bacillus licheniformis chitinase (ChiA), suitable for bioconversion of chitin waste. Bioresour. Technol. 2010, 101, 4096-4103. [CrossRef] [PubMed]

5. Muzzarelli, R.A.; Mattioli-Belmonte, M.; Pugnaloni, A.; Biagini, G. Biochemistry, histology and clinical uses of chitins and chitosans in wound healing. EXS 1999, 87, 251-264. [CrossRef] [PubMed]

6. Matica, M.A.; Aachmann, F.L.; Tøndervik, A.; Sletta, H.; Ostafe, V. Chitosan as a wound dressing starting material: Antimicrobial properties and mode of action. Int. J. Mol. Sci. 2019, 20, 5889. [CrossRef]

7. Mincea, M.; Negrulescu, A.; Ostafe, V. Preparation, modification, and applications of chitin nanowhiskers: A review. Rev. Adv. Mater. Sci. 2012, 30, 225-242.

8. Oyeleye, A.; Normi, Y.M. Chitinase: Diversity, limitations, and trends in engineering for suitable applications. Biosci. Rep. 2018, 38, 2018032300. [CrossRef] [PubMed]

9. Ostafe, R.; Prodanovic, R.; Nazor, J.; Fischer, R. Ultra-high-throughput screening method for the directed evolution of glucose oxidase. Chem. Biol. 2014, 21, 414-421. [CrossRef]

10. Prodanovic, R.; Ostafe, R.; Scacioc, A.; Schwaneberg, U. Ultrahigh throughput screening system for directed glucose oxidase evolution in yeast cells. Comb. Chem. High Throughput Screen. 2010, 14, 55-60. [CrossRef]

11. Farinas, E.; Schwaneberg, U.; Glieder, A.; Arnold, F. Directed evolution of a cytochrome P450 monooxygenase for alkane oxidation. Adv. Synth. Catal. 2001, 343. [CrossRef]

12. Goedegebuur, F.; Dankmeyer, L.; Gualfetti, P.; Karkehabadi, S.; Hansson, H.; Jana, S.; Huynh, V.; Kelemen, B.R.; Kruithof, P.; Larenas, E.A.; et al. Improving the thermal stability of cellobiohydrolase Cel7A from Hypocrea jecorina by directed evolution. J. Biol. Chem. 2017, 292, 17418-17430. [CrossRef]

13. Đurđić, I.K.; Ece, S.; Ostafe, R.; Vogel, S.; Schillberg, S.; Fischer, R.; Prodanović, R. Improvement in oxidative stability of versatile peroxidase by flow cytometry-based high-throughput screening system. Biochem. Eng. J. 2020, 157, 107555. [CrossRef]

14. Blažić, M.; Balaž, A.M.; Tadić, V.; Draganić, B.; Ostafe, R.; Fischer, R.; Prodanović, R. Protein engineering of cellobiose dehydrogenase from Phanerochaete chrysosporium in yeast Saccharomyces cerevisiae Invsc1 for increased activity and stability. Biochem. Eng. J. 2019, 146, 179-185. [CrossRef]

15. Weiß, M.S.; Pavlidis, I.V.; Spurr, P.; Hanlon, S.P.; Wirz, B.; Iding, H.; Bornscheuer, U.T. Protein-engineering of an amine transaminase for the stereoselective synthesis of a pharmaceutically relevant bicyclic amine. Org. Biomol. Chem. 2016, 14, 10249-10254. [CrossRef] [PubMed]

16. Giver, L.; Gershenson, A.; Freskgard, P.-O.; Arnold, F.H. Directed evolution of a thermostable esterase. Proc. Natl. Acad. Sci. USA 1998, 95, 12809-12813. [CrossRef] 
17. Liebeton, K.; Zonta, A.; Schimossek, K.; Nardini, M.; Lang, D.; Dijkstra, B.W.; Reetz, M.T.; Jaeger, K.E. Directed evolution of an enantioselective lipase. Chem. Biol. 2000, 7, 709-718. [CrossRef]

18. Yoo, T.H.; Pogson, M.; Iverson, B.L.; Georgiou, G. Directed evolution of highly selective proteases by using a novel FACS-based screen that capitalizes on the p53 regulator MDM2. ChemBioChem 2012, 13, 649-653. [CrossRef] [PubMed]

19. Fan, Y.; Fang, W.; Xiao, Y.; Yang, X.; Zhang, Y.; Bidochka, M.J.; Pei, Y. Directed evolution for increased chitinase activity. Appl. Microbiol. Biotechnol. 2007, 76, 135-139. [CrossRef] [PubMed]

20. Songsiriritthigul, C.; Pesatcha, P.; Eijsink, V.G.; Yamabhai, M. Directed evolution of a Bacillus chitinase. Biotechnol. J. 2009, 4, 501-509. [CrossRef]

21. Wang, S.; Fu, G.; Li, J.; Wei, X.; Fang, H.; Huang, D.; Lin, J.; Zhang, D. High-efficiency secretion and directed evolution of chitinase bcchia1 in Bacillus subtilis for the conversion of chitinaceous wastes into chitooligosaccharides. Front. Bioeng. Biotechnol. 2020, 8 , 432. [CrossRef] [PubMed]

22. Neylon, C. Chemical and biochemical strategies for the randomization of protein encoding DNA sequences: Library construction methods for directed evolution. Nucleic Acids Res. 2004, 32, 1448-1459. [CrossRef]

23. Cirino, P.C.; Mayer, K.M.; Umeno, D.; Arnold, F.H.; Georgiou, G. Generating mutant libraries using error-prone PCR. In Directed Evolution Library Creation; Humana Press: Totowa, NJ, USA, 2003; pp. 3-9. [CrossRef]

24. Fujii, R.; Kitaoka, M.; Hayashi, K. Error-prone rolling circle amplification: The simplest random mutagenesis protocol. Nat. Protoc. 2006, 1, 2493. [CrossRef]

25. Packer, M.S.; Liu, D.R. Methods for the directed evolution of proteins. Nat. Rev. Genet. 2015, 16, 379-394. [CrossRef]

26. Xiao, H.; Bao, Z.; Zhao, H. High throughput screening and selection methods for directed enzyme evolution. Ind. Eng. Chem. Res. 2015, 54, 4011-4020. [CrossRef]

27. Yang, J.; Liu, X.; Sun, S.; Liu, X.; Yang, L. Screening platform based on robolid microplate for immobilized enzyme-based assays. ACS Omega 2017, 2, 5079-5086. [CrossRef]

28. Griffiths, A.D.; Tawfik, D.S. Directed evolution of an extremely fast phosphotriesterase by in vitro compartmentalization. $E M B O$ J. 2003, 22, 24-35. [CrossRef]

29. Mastrobattista, E.; Taly, V.; Chanudet, E.; Treacy, P.; Kelly, B.T.; Griffiths, A.D. High-throughput screening of enzyme libraries: In vitro evolution of a B-galactosidase by fluorescence-activated sorting of double emulsions. Chem. Biol. 2005, 12, 1291-1300. [CrossRef] [PubMed]

30. Tawfik, D.S.; Griffiths, A.D. Man-made cell-like compartments for molecular evolution. Nat. Biotechnol. 1998, 16, 652-656. [CrossRef] [PubMed]

31. Yang, G.; Rich, J.R.; Gilbert, M.; Wakarchuk, W.W.; Feng, Y.; Withers, S.G. Fluorescence activated cell sorting as a general ultra-high-throughput screening method for directed evolution of glycosyltransferases. J. Am. Chem. Soc. 2010, 132, 10570-10577. [CrossRef] [PubMed]

32. Ruff, A.J.; Dennig, A.; Wirtz, G.; Blanusa, M.; Schwaneberg, U. Flow cytometer-based high-throughput screening system for accelerated directed evolution of P450 monooxygenases. ACS Catal. 2012, 2, 2724-2728. [CrossRef]

33. Körfer, G.D.J.; Pitzler, C.; Vojcic, L.; Martinez, R.; Schwaneberg, U. In vitro flow cytometry-based screening platform for cellulase engineering. Sci. Rep. 2016, 6, 26128. [CrossRef]

34. Markel, U.; Essani, K.D.; Besirlioglu, V.; Schiffels, J.; Streit, W.R.; Schwaneberg, U. Advances in ultrahigh-throughput screening for directed enzyme evolution. Chem. Soc. Rev. 2020, 49, 233-262. [CrossRef]

35. Arnold, F.H. The nature of chemical innovation: New enzymes by evolution. Q. Rev. Biophys. 2015, 48, 404-410. [CrossRef]

36. Kaczmarek, B.M.; Struszczyk-Swita, K.; Li, X.; Szczęsna-Antczak, M.; Daroch, M. Enzymatic modifications of chitin, chitosan, and chitooligosaccharides. Front. Bioeng. Biotechnol. 2019, 7, 243. [CrossRef] [PubMed]

37. Menghiu, G.; Ostafe, V.; Prodanovic, R.; Fischer, R.; Ostafe, R. Biochemical characterization of chitinase a from Bacillus licheniformis Dsm8785 expressed in Pichia pastoris KM71H. Protein Expr. Purif. 2019, 154, 25-32. [CrossRef] [PubMed]

38. Raunio, H.; Pentikäinen, O.; Juvonen, R.O. Coumarin-based profluorescent and fluorescent substrates for determining xenobioticmetabolizing enzyme activities in vitro. Int. J. Mol. Sci. 2020, 21, 4708. [CrossRef] [PubMed]

39. Gee, R.K.; Sun, W.C.; Bhalgat, M.K.; Upson, R.H.; Klaubert, D.H.; Latham, K.A.; Haugland, R.P. Fluorogenic substrates based on fluorinated umbelliferones for continuous assays of phosphatases and B-galactosidases. Anal. Biochem. 1999, $273,41-48$. [CrossRef]

40. Pritsch, K.; Raidl, S.; Marksteiner, E.; Blaschke, H.; Agerer, R.; Schloter, M.; Hartmann, A. A Rapid and highly sensitive method for measuring enzyme activities in single mycorrhizal tips using 4-methylumbelliferone-labelled fluorogenic substrates in a microplate system. J. Microbiol. Methods 2004, 58, 233-241. [CrossRef]

41. Blažić, M.; Balaž, A.M.; Prodanović, O.; Popović, N.; Ostafe, R.; Fischer, R.; Prodanović, R. Directed evolution of cellobiose dehydrogenase on the surface of yeast cells using resazurin-based fluorescent assay. Appl. Sci. 2019, 9, 1413. [CrossRef]

42. Tiwari, G.; Tiwari, R.; Rai, A.K. Cyclodextrins in delivery systems: Applications. J. Pharm. Bioallied Sci. 2010, 2, 72-79. [CrossRef]

43. Winger, T. Enzymatic Assays Using Umbelliferone Substrates with Cyclodextrins in Droplets in Oil. U.S. Patent 8,093,062, 10 January 2012.

44. Peng, A.C.; Hsu, Y.C. Perfluorocarbon-Soluble Compounds. U.S. Patent WO/2005/107764, 17 November 2005.

45. Fontana, M.; Costa, M.; Mosca, L.; Rosei, M.A. A specific assay for discriminating between peroxidase and lipoxy-genase activities. Biochem. Mol. Biol. Int. 1997, 42, 163-168. [CrossRef] 
46. Rathore, A.S.; Gupta, R.D. Chitinases from bacteria to human: Properties, applications, and future perspectives. Enzym. Res. 2015, 1-8. [CrossRef] [PubMed]

47. Lobo, M.D.P.; Silva, F.D.A.; Landim, P.G.D.C.; Da Cruz, P.R.; De Brito, T.L.; De Medeiros, S.C.; Oliveira, J.T.A.; Vasconcelos, I.M.; Pereira, H.D.; Grangeiro, T.B. Expression and efficient secretion of a functional chitinase from Chromobacterium violaceum in Escherichia coli. BMC Biotechnol. 2013, 13, 1-46. [CrossRef] [PubMed]

48. Liu, Z.; Huang, Y.; Zhang, R.; Diao, G.; Fan, H.; Wang, Z. Chitinase genes Lbchi31 and Lbchi32 from Limonium bicolor were successfully expressed in Escherichia coli and exhibit recombinant chitinase activities. Sci. World J. 2013, 648382. [CrossRef]

49. Okazaki, K.; Yamashita, Y.; Noda, M.; Sueyoshi, N.; Kameshita, I.; Hayakawa, S. Molecular cloning and expression of the gene encoding family 19 chitinase from Streptomyces sp. J-13-3. Biosci. Biotechnol. Biochem. 2004, 68, 341-351. [CrossRef]

50. Pettersen, F.E.; Goddard, T.D.; Huang, C.C.; Couch, G.S.; Greenblatt, D.M.; Meng, E.C.; Ferrin, T.E. UCSF Chimera-A visualization system for exploratory research and analysis. J. Comput. Chem. 2004, 25, 1605-1612. [CrossRef]

51. Henikoff, S.; Henikoff, J.G. Amino acid substitution matrices from protein blocks. Proc. Natl. Acad. Sci. USA 1992, 89, 10915-10919. [CrossRef] [PubMed]

52. Ashenberg, O.; Gong, L.I.; Bloom, J.D. Mutational effects on stability are largely conserved during protein evolution. Proc. Natl. Acad. Sci. USA 2013, 110, 21071-21076. [CrossRef]

53. Zhou, H.-X.; Pang, X. Electrostatic interactions in protein structure, folding, binding, and condensation. Chem. Rev. 2018, 118, 1691-1741. [CrossRef]

54. Lee, H.S.; Ryu, E.J.; Kang, M.J.; Wang, E.S.; Piao, Z.; Choi, Y.J.; Jung, K.H.; Jeon, J.Y.J.; Shin, Y.C. A new approach to directed gene evolution by recombined extension on truncated templates (RETT). J. Mol. Catal. B Enzym. 2003, 26, 119-129. [CrossRef]

55. Arnold, H.F.; Georgiou, G. Directed Enzyme Evolution. Screening and Selection Methods; Humana Press: Totowa, NJ, USA, 2003.

56. Ostafe, R.; Prodanovic, R.; Commandeur, U.; Fischer, R. Flow cytometry-based ultra-high-throughput screening assay for cellulase activity. Anal. Biochem. 2013, 435, 93-98. [CrossRef] [PubMed]

57. Sanger, F.; Nicklen, S.; Coulson, A.R. DNA sequencing with chain-terminating inhibitors. Proc. Natl. Acad. Sci. USA 1977, 74, 5463-5467. [CrossRef]

58. Waterhouse, A.; Bertoni, M.; Bienert, S.; Studer, G.; Tauriello, G.; Gumienny, R.; Heer, F.T.; de Beer, T.A.P.; Rempfer, C.; Bordoli, L.; et al. SWISS-MODEL: Homology modelling of protein structures and complexes. Nucleic Acids Res. 2018, 46, W296-W303. [CrossRef] 